\title{
HUBUNGAN KESIAPAN BELAJAR, MANAJEMEN WAKTU, KECEMASAN DALAM MENGERJAKAN TES, DAN HASIL BELAJAR MATA PELAJARAN TEKNIK LISTRIK DASAR OTOMOTIF SISWA SMK
}

\begin{abstract}
Wira Yogo Minarto
Abstrak: Tujuan penelitian adalah untuk mendeskripsikan kesiapan belajar, manajemen waktu, kecemasan dalam mengerjakan tes, dan hasil belajar siswa kelas X Teknik Kendaraan Ringan pada mata pelajaran Teknik Listrik Dasar Otomotif di SMK Islam 1 Blitar, dan untuk menguji signifikansi hubungan variabel bebas dengan hasil belajar siswa secara simultan dan secara parsial. Sampel berjumlah 146 siswa dengan metode Simple Random Sampling. Pengambilan data menggunakan angket dan dokumentasi, dengan analisis regresi linier berganda. Hasil penelitian menunjukkan terdapat hubungan yang signifikan secara simultan kesiapan belajar, manajemen waktu, dan kecemasan dalam mengerjakan tes dengan hasil belajar, ada hubungan positif yang signifikan kesiapan belajar dengan hasil belajar, manajemen waktu dengan hasil belajar, dan ada hubungan negatif yang signifikan kecemasan dalam mengerjakan tes dengan hasil belajar.
\end{abstract}

Kata-kata Kunci: kesiapan belajar, manajemen waktu, kecemasan dalam mengerjakan tes, hasil belajar

Abstract: The Relationship between Learning Readiness, Time Management, Anxiety in Tests Working, and Learning Outcomes of Basic Automotive Electrical Engineering Subjects for SMK Students. The study aimed to describe the learning readiness, time management, anxiety in working a test and the learning outcomes of $10^{\text {th }}$ Grade students at Department of Light Vehicle Engineering on Basic Automotive Electrical Engineering subject in Public Vocational High School 1 Blitar and to test the significance of relationship between the independent variables and the students learning outcomes both simultaneously and partially. The samples in this research was 146 students taken by using a simple random sampling method. Data collection was performed by using questionnaire and documentation, and analyzed by multiple regression linear analysis. This study showed that there was a significant relationship, simultaneously, between learning readiness, time management, and anxiety in working a test with the learning outcome. In addition, partially, there was also a significant relationship between learning readiness and learning outcome; time management and learning outcome; and there was also a significant relationship between anxiety in working a test and learning outcome.

Keywords: learning readiness, time management, anxiety in working a test, learning outcome

Sekolah Menengah Kejuruan (SMK) Stermasuk ke dalam jenis pendidikan formal dan dalam jenjang pendidikan me- nengah. SMK menurut pasal 15 UndangUndang No. 20 Tahun 2003 tentang Sistem Pendidikan Nasional didefinisikan

Wora Yoga Minarto adalah Asisten PT Sumito Teknik Email: wirayogominarto@gmail.com. Alamat Kantor: Wono Rungkut Utara II 9, Wonorejo, Rungkut, Kota Surabaya, Jawa Timur 60296. 
bahwa pendidikan kejuruan merupakan pendidikan menengah yang mempersiapkan peserta didik terutama untuk bekerja dalam bidang tertentu. Lebih spesifik dijelaskan dalam PP No. 29 Tahun 1990 tentang Pendidikan Menengah menjelaskan bahwa pendidikan menengah kejuruan adalah pendidikan pada jenjang pendidikan menengah yang mengutamakan pengembangan kemampuan siswa untuk jenis pekerjaan tertentu (Pemerintah RI, 1990).

Berdasarkan penjelesan tentang pendidikan kejuruan (Pemerintah RI, 1990) diketahui bahwa SMK dituntut untuk menghasilkan lulusan yang mempunyai kompetensi di bidangnya sehingga mampu bersaing di dunia kerja skala nasional maupun internasional. SMK Islam 1 Blitar memiliki 5 kompetensi keahlian yang salah satu diantaranya adalah Teknik Kendaraan Ringan (TKR). Pada kompetensi keahlian TKR siswa mendapatkan mata pelajaran Produktif yang di dalamnya terdapat mata pelajaran Teknik Listrik Dasar Otomotif (TLDO). Mata pelajaran TLDO merupakan mata pelajaran yang membekali peserta didik untuk mampu mengusai teori dasar kelistrikan, mengenali komponen dasar elektronika, dan mampu menggunakan alat ukur kelistrikan. Mata pelajaran TLDO sangat penting bagi peserta didik kompetensi keahlian TKR karena sangat dibutuhkan untuk praktikum bengkel di kelas XI, Prakerin di Industri, Uji Kompetensi Keahlian (UKK) di kelas XII, dan juga pada saat kerja nantinya.

Hasil belajar merupakan hasil dari suatu interaksi tindak belajar dan tindak mengajar yang diakhiri dengan evaluasi hasil belajar sebagai pencapaian tujuan pengajaran (Dimyati dan Mudjiono, 2009:3). Hasil belajar tersebut berupa nilai kognitif, afektif, dan psikomotorik yang digunakan guru untuk mengukur tingkat keberhasilan siswa dalam mempelajari materi yang telah diajarkan yang ditulis pada rapor siswa. Ketuntasan siswa dalam menempuh mata pelajaran TLDO ditunjukkan pada hasil belajar yaitu nilai rapor yang diambil dari nilai UTS dan nilai UAS. Dalam penelitian ini nilai UAS semester Gasal tahun ajaran 2016/ 2017 digunakan sebagai hasil belajar siswa karena nilai tersebut merupakan nilai murni dari siswa.

Kesiapan belajar yaitu keseluruhan kondisi seseorang yang membuatnya siap untuk memberikan respon/jawaban di dalam proses belajar (Rice-Spearman dalam Widyaningtyas, dkk., 2013:137). Kesiapan belajar dapat diartikan kondisi awal yang membuat diri siswa siap untuk mempelajari materi pelajaran dan merespon atau menanggapi suatu hal dalam kegiatan belajar.

Berdasarkan hasil observasi dan wawancara dengan guru mata pelajaran TLDO di SMK Islam 1 Blitar menunjukkan bahwa masih terdapat siswa yang memiliki nilai hasil belajar yang rendah dan di bawah Kriteria Ketuntasan Minimum (KKM). Kesiapan belajar berperan penting bagi siswa dalam mencapai tujuan pembelajaran, sebagaimana diungkapkan Darso (2011:158) bahwa kesiapan belajar siswa adalah faktor yang harus dimiliki oleh siswa dalam menghadapi kegiatan pembelajaran. Mengingat bahwa kegiatan belajar akan berhasil jika siswa memiliki kesiapan yang tinggi. Betapa pentingnya kesiapan belajar sebelum memulai proses pembelajaran juga diungkapkan Drever dalam Slameto (2013:59) kesiapan ini perlu diperhatikan dalam proses belajar, karena jika siswa belajar dan padanya sudah ada kesiapan, maka hasil belajarnya akan lebih baik. Berarti, jika siswa memiliki kesiapan belajar yang matang maka siswa dapat merespon pelajaran dan mampu memperoleh hasil belajar yang bagus.

Selain kesiapan belajar, manajemen waktu merupakan hal yang penting bagi siswa dalam mencapai hasil belajar yang 
optimal. Hasil wawancara dengan wakil kepala sekolah bidang Kurikulum, menunjukkan bahwa siswa SMK Islam 1 Blitar menempuh mata pelajaran produktif yang memiliki jumlah mata pelajaran yang banyak sehingga banyak juga materi yang harus dipelajari dan dipahami. Menurut hasil wawancara dengan beberapa siswa, diketahui bahwa siswa masih belum mampu mengatur waktu belajarnya seperti tidak membuat jadwal belajar dan tugas rumah yang harus dikerjakan.

Selain hal tersebut, hasil belajar juga dipengaruhi oleh kondisi siswa dalam mengerjakan soal tes ulangan atau ujian. Slameto (2013) menyatakan bahwa faktor-faktor yang dapat berhubungan dengan prestasi/hasil belajar siswa digolongkan menjadi dua golongan, yaitu faktor internal dan eksternal. Salah satu faktor internal yang berpengaruh terhadap prestasi/hasil belajar antara lain kecemasan dalam mengerjakan tes.

Post (1978) menyatakan bahwa kecemasan adalah kondisi emosional yang tidak menyenangkan yang ditandai oleh perasaan-perasaan subjektif seperti ketegangan, ketakutan, kekhawatiran dan juga ditandai dengan aktifnya sistem saraf pusat. Seperti fakta yang ditemukan di SMK Islam 1 Blitar, beberapa siswa merasa khawatir dan takut gagal dalam mengerjakan tes. Mereka mengaku bahwa mereka takut tidak bisa mengerjakan tes yang diberikan sehingga akan mendapatkan nilai yang jelek bahkan sampai tidak lulus.

Tujuan penelitian ini adalah: (1) Mendeskripsikan kesiapan belajar siswa; (2) Mendeskripsikan manajemen waktu siswa; (3) Mendeskripsikan kecemasan siswa dalam mengerjakan tes; (4) Mendeskripsikan hasil belajar siswa; (5) Menguji apakah ada hubungan kesiapan belajar, manajemen waktu, dan kecemasan dalam mengerjakan tes dengan hasil belajar; (6) Menguji apakah ada hubungan kesiapan belajar dengan hasil belajar;
(7) Menguji apakah ada hubungan manajemen waktu dengan hasil belajar; dan (8) Menguji apakah ada hubungan kesiapan belajar.

\section{METODE}

Penelitian ini termasuk penelitian deskriptif korelasional yang bertujuan untuk mengetahui hubungan antar variabel penelitian. Variabel bebas dalam penelitian ini adalah kesiapan belajar, manajemen waktu, kecemasan dalam mengerjakan tes, dan hasil belajar.

Populasi penelitian ini adalah siswa Kelas X TKR di SMK Islam 1 Blitar yang berjumlah 229 dan jumlah sampel sebanyak 146 dengan menggunakan teknik simple random sampling. Alat pengumpulan data berupa angket dan dokumentasi. Prosedur yang ditempuh dalam pengumpulan data adalah dengan tallies data dari angket. Data yang telah terkumpul akan dianalisis dengan menggunakan teknik deskriptif meliputi mean, standar deviasi, dan distribusi kelas berbentuk persentase, analisis regresi linear berganda, uji $\mathrm{F}$, dan uji $t$ dengan bantuan program SPSS 17.0 for windows.

\section{HASIL}

Berdasarkan temuan tentang kesiapan belajar, manajemen waktu, kecemasan dalam mengerjakan tes, dan hasil belajar. Berdasarkan Tabel 1 diketahui bahwa: (1) 53 responden atau $35,62 \%$ memiliki kesiapan belajar dengan kategori tinggi; (2) 90 responden atau $61,64 \%$ memiliki kesiapan belajar dengan kategori sedang;

Tabel 1. Distribusi Kesiapan Belajar

\begin{tabular}{cccc}
\hline Kategori & Skor & F & Persentase (\%) \\
\hline Tinggi & $\geq 53$ & 53 & 35,62 \\
Sedang & $39-52$ & 90 & 61,64 \\
Rendah & $<39$ & 4 & 2,74 \\
\hline Total & & 146 & 100,00 \\
\hline
\end{tabular}


Tabel 2. Distribusi Manajemen Waktu

\begin{tabular}{cccc}
\hline Kategori & Skor & F & Persentase (\%) \\
\hline Tinggi & $\geq 50$ & 36 & 24,66 \\
Sedang & $36-49$ & 84 & 57,53 \\
Rendah & $<36$ & 26 & 17,81 \\
\hline Total & 146 & 100,00 \\
\hline
\end{tabular}

Tabel 3. Distribusi Kecemasan dalam Mengerjakan Tes

\begin{tabular}{cccc}
\hline Kategori & Skor & F & Persentase (\%) \\
\hline Tinggi & $>63$ & 24 & 16,440 \\
Sedang & $45-62$ & 81 & 55,480 \\
Rendah & $<45$ & 41 & 28,080 \\
\hline Total & 146 & 100,00 \\
\hline
\end{tabular}

Tabel 4. Distribusi Hasil Belajar

\begin{tabular}{cccc}
\hline Kategori & Skor & F & Persentase (\%) \\
\hline Tinggi & $\geq 87$ & 41 & 28,08 \\
Cukup & $73-86$ & 97 & 66,44 \\
Rendah & $<73$ & 8 & 5,48 \\
\hline Total & 146 & 100,00 \\
\hline
\end{tabular}

dan (3) 4 responden atau $2,74 \%$ memiliki kesiapan belajar dengan kategori rendah.

Berdasarkan Tabel 2 diketahui bahwa: (1) 36 responden atau 24,66\% memiliki manajemen waktu dengan kategori tinggi; (2) 84 responden atau 57,53\% memiliki manajemen waktu dengan kategori sedang; dan (3) 26 responden atau $17,81 \%$ memiliki manajemen waktu dengan kategori rendah.

Berdasarkan Tabel 3 diketahui bahwa: (1) 24 responden atau $16,44 \%$ memiliki kecemasan dalam mengerjakan tes dengan kategori tinggi; (2) 81 responden atau 55,48\% memiliki kecemasan dalam mengerjakan tes dengan kategori sedang; dan (3) 41 responden atau 28,08\% memiliki kecemasan dalam mengerjakan tes dengan kategori rendah.

Berdasarkan Tabel 4 hasil pengolahan data variabel hasil belajar diketahui bahwa: (1) 41 responden atau 28,08\% memiliki hasil belajar dengan kategori tinggi; (2) 97 responden atau $66,44 \%$ memiliki hasil belajar dengan kategori sedang; dan (3) 8 responden atau 5,48\% memiliki hasil belajar dengan kategori rendah.

Pada Tabel 5 terlihat sig $=0,000<$ 0,05, maka $\mathrm{H}_{0}$ yang berbunyi tidak ada hubungan yang signifikan kesiapan belajar siswa, manajemen waktu, kecemasan dalam mengerjakan tes, dengan hasil belajar ditolak, dengan kata lain ada hubungan yang signifikan kesiapan belajar, manajemen waktu, kecemasan dalam mengerjakan tes dengan hasil belajar siswa Kelas X TKR pada mata pelajaran TLDO di SMK Islam 1 Blitar.

Pada Tabel 6 variabel Kesiapan Belajar $\left(\mathrm{X}_{1}\right)$ sig $=0,000$, maka $\mathrm{H}_{0}$ yang berbunyi tidak ada hubungan yang signifikan variabel kesiapan belajar dengan hasil belajar ditolak, dengan kata lain ada hubungan yang signifikan variabel $\mathrm{Ke}$ siapan Belajar $\left(\mathrm{X}_{1}\right)$ dengan Hasil Belajar (Y) siswa Kelas X TKR pada mata pelajaran TLDO di SMK Islam 1 Blitar.

Tabel 5. Hasil Uji F

\begin{tabular}{lcccc}
\hline Model & Sum of Squares & Df & Mean Square & SSig. \\
\hline Regression & 4110.093 & 3 & 1370.031 & $.000^{\mathrm{a}}$ \\
Residual & 4899.386 & 142 & 34.503 & \\
\hline Total & 9009.479 & 145 & & \\
\hline
\end{tabular}

Tabel 6. Rangkuman Hasil Uji $t$

\begin{tabular}{lcc}
\hline \multicolumn{1}{c}{ Model } & T & Sig. \\
\hline (Constant) & 12.265 & .000 \\
Kesiapan Belajar & 3.704 & .000 \\
Manajemen Waktu & 5.101 & .000 \\
Kecemasan dalam Mengerjakan Tes & -2.524 & .013 \\
\hline
\end{tabular}




\section{PEMBAHASAN}

Mengacu kepada hasil penelitian di atas, berikut dipaparkan pembahasan hasil penelitian. Siswa Kelas X kompetensi keahlian TKR di SMK Islam 1 Blitar memiliki kesiapan belajar pada mata pelajaran TLDO dalam kategori sedang. Dapat diartikan bahwa siswa mampu mempersiapkan kondisi dirinya dengan baik untuk memulai kegiatan belajar dan merespon/bertindak dalam menghadapi situasi dalam pembelajaran agar mendapatkan hasil yang lebih baik. Slameto (2013: 113) bahwa keseluruhan kondisi seseorang yang membuatnya siap untuk memberi respon atau jawaban di dalam cara tertentu terhadap suatu situasi. Kesiapan belajar juga dapat dikatakan bahwa murid yang telah siap belajar untuk melakukan kegiatan belajar agar lebih mudah dan lebih berhasil (Hamalik, 2008:33).

Manajemen waktu siswa Kelas X kompetensi keahlian TKR di SMK Islam 1 berada dalam kategori sedang. Dapat diartikan bahwa siswa mampu mengatur dan memanfaatkan waktu dengan baik untuk belajar dan menyelesaikan tugas sekolahnya. Akram (2010: 19) menyatakan bahwa manajemen waktu adalah memanfaatkan waktu yang anda miliki untuk melakukan hal-hal yang dianggap penting yang telah tercatat dalam tabel kerja. Hal tersebut juga didukung oleh pendapat Sandra dan Djalali (2013:219) yang menegaskan bahwa manajemen waktu adalah kemampuan untuk mengalokasikan waktu dan sumber daya untuk mencapai tujuan.

Kecemasan siswa Kelas X kompetensi keahlian TKR di SMK Islam 1 Blitar dalam mengerjakan tes berada pada kategori sedang. Dapat diartikan bahwa siswa masih mengalami kecemasan dalam mengerjakan tes, yang bisa menurunkan kinerja otak siswa dalam mengerjakan tes. Lubis (2009:14) mengatakan kecemasan merupakan perasaan yang dialami ketika berpikir tentang sesuatu yang tidak menyenangkan yang akan terjadi. Didukung oleh pernyataan Daradjat dalam (Mursyidi, 2010) mengungkapkan kecemasan merupakan adanya perasaan tidak menentu, rasa panik, adanya rasa takut dan ketidakmampuan individu untuk memahami sumber ketakutannya

Siswa kelas X kompetensi keahlian TKR di SMK Islam 1 Blitar pada mata pelajaran TLDO mendapatkan hasil belajar dalam kategori sedang. Dapat diartikan bahwa mayoritas siswa telah tuntas menempuh mata pelajaran TLDO. Hasil belajar dalam penelitian ini menggunakan nilai kognitif Ujian Akhir Semester Gasal tahun ajaran 2016/2017, karena menurut Djamarah dan Zain (2010:106) bahwa untuk mengukur dan mengevaluasi tingkat keberhasilan belajar dapat dilakukan melalui tes prestasi belajar salah satunya dengan tes sumatif yang bertujuan untuk mengukur daya serap siswa terhadap bahan pokok bahasan yang telah diajarkan selama satu semester. Selain itu, karena menurut Darso (2011: 154) bahwa di dalam proses pembelajaran digunakan metode penerapan pembelajaran dengan pemberian kemampuan pada penguasaan sejumlah teori yang lebih menekankan pada aspek kognitif.

Terdapat hubungan yang signifikan antara kesiapan belajar, manajemen waktu, dan kecemasan dalam mengerjakan tes secara bersama-sama dengan hasil belajar siswa Kelas X TKR pada mata pelajaran Teknik Listrik Dasar Otomotif di SMK Islam 1 Blitar. Dalyono (2009) bahwa hasil belajar dipengaruhi oleh faktor internal dan faktor eksternal. Faktor internal yaitu kesehatan, intelegensi, bakat, minat, motivasi, dan cara belajar, sedangkan faktor eksternal yaitu keadaan keluarga, keadaan sekolah, keadaan masyarakat, dan lingkungan sekitar. 
Ada hubungan positif yang signifikan kesiapan belajar dengan hasil belajar Siswa Kelas X TKR pada mata pelajaran TLDO di SMK Islam 1 Blitar. Sejalan dengan pendapat Slameto (2013: 59) bahwa kesiapan belajar adalah kesediaan untuk memberi respon atau bereaksi yang timbul dari dalam diri seseorang dan juga berhubungan dengan kematangan, karena kematangan berarti kesiapan untuk melaksanakan kecakapan. Dapat dikatakan jika siswa belajar dengan sungguh-sungguh dan mempersiapkan segala penunjang kebutuhan pembelajaran maka akan mendapatkan hasil belajar yang memuaskan.

Ada hubungan positif yang signifikan manajemen waktu dengan hasil belajar Siswa Kelas X TKR pada mata pelajaran Teknik Listrik Dasar Otomotif di SMK Islam 1 Blitar. Sejalan dengan pendapat Djamarah dan Zain (2010: 24) bahwa masalah pengaturan waktu menjadi persoalan bagi pelajar. Manajemen waktu menjadi salah satu faktor pendukung tercapainya tujuan belajar siswa yang memperoleh hasil belajar yang baik.

Ada hubungan negatif yang signifikan kecemasan dalam mengerjakan tes dengan hasil belajar Siswa Kelas X TKR pada mata pelajaran TLDO di SMK Islam 1 Blitar. Sejalan dengan pendapat Sudrajat (2008) yang mengatakan bahwa kecemasan yang muncul tersebut akan berdampak negatif terhadap hasil ujian yang akan diperoleh oleh masing-masing siswa yang mengalami intensitas kecemasan yang terlalu tinggi. Cattel dalam (Rosdiana, 2008) yang menyatakan kecemasan pada situasi tertentu akan dirasakan sebagai ancaman, tidak lulus ujian atau saat menghadapi ujian. Adapun kondisi yang tidak terkendali dan tidak menyenangkan tersebut yaitu: sulit berkonsentrasi, bingung memilih jawaban yang benar, mental blocking, khawatir, takut gelisah, gemetar pada saat mengerjakan tes.

\section{SIMPULAN DAN SARAN}

Berdasarkan hasil penelitian dan pembahasan yang telah diuraikan, maka dapat diambil kesimpulan sebagai berikut. Kondisi kesiapan belajar siswa Kelas $X$ TKR pada mata pelajaran TLDO di SMK Islam 1 Blitar berada pada kategori sedang, sehingga dapat disimpulkan bahwa siswa cukup siap untuk melakukan proses pembelajaran. Kondisi manajemen waktu siswa Kelas X TKR pada mata pelajaran TLDO di SMK Islam 1 Blitar berada pada kategori sedang, sehingga dapat disimpulkan bahwa siswa cukup mampu untuk mengelola waktunya. Kondisi kecemasan dalam mengerjakan tes belajar siswa Kelas X TKR pada mata pelajaran TLDO di SMK Islam 1 Blitar berada pada kategori sedang, sehingga dapat disimpulkan bahwa siswa masih banyak yang merasa cemas saat mengerjakan soal tes ujian. Siswa Kelas X TKR di SMK Islam 1 Blitar memiliki hasil belajar dalam kategori sedang pada mata pelajaran TLDO, sehingga dapat disimpulkan bahwa siswa banyak yang telah menuntaskan mata pelajaran TLDO dengan hasil yang memuaskan.

Ada hubungan yang signifikan secara simultan kesiapan belajar, manajemen waktu, dan kecemasan dalam mengerjakan tes dengan hasil belajar siswa Kelas X TKR pada mata pelajaran TLDO di SMK Islam 1 Blitar. Hal ini berarti variabel kesiapan belajar, manajemen waktu, dan kecemasan dalam mengerjakan tes erat kaitannya dengan hasil belajar. Ada hubungan positif yang signifikan kesiapan belajar dengan hasil belajar siswa Kelas X TKR pada mata pelajaran TLDO di SMK Islam 1 Blitar. Semakin tinggi kesiapan belajar maka akan semakin tinggi hasil belajar. Hal ini berarti kesiapan belajar merupakan salah satu faktor yang menyumbang dampak positif hasil belajar.

Ada hubungan positif yang signifikan manajemen waktu dengan hasil 
belajar siswa Kelas X TKR pada mata pelajaran TLDO di SMK Islam Blitar. Semakin tinggi manajemen waktu maka akan semakin tinggi hasil belajar. Hal ini berarti manajemen waktu merupakan salah satu faktor yang menyumbang dampak positif hasil belajar. Ada hubungan negatif yang signifikan kecemasan dalam mengerjakan tes dengan hasil belajar siswa Kelas X TKR pada mata pelajaran TLDO di SMK Islam 1 Blitar. Semakin tinggi kecemasan dalam mengerjakan tes maka akan semakin rendah hasil belajar. Hal ini berarti kecemasan dalam mengerjakan tes berdampak negatif terhadap hasil belajar.

Beberapa saran yang dapat diberikan berdasarkan hasil penelitian adalah sebagai berikut. Bagi siswa untuk mempersiapkan kondisi sebelum melaksanakan proses pembelajaran. Kondisi tersebut meliputi kondisi fisik, psikis, dan materiil. Kesiapan belajar berhubungan dengan hasil belajar, sehingga jika kesiapan siswa semakin baik akan berdampak positif dalam memperoleh hasil belajar. Selain itu, siswa juga diharapkan mampu mengelola waktu belajarnya secara optimal. Hal ini bertujuan untuk meningkatkan prestasi atau hasil belajarnya karena manajemen waktu berdampak positif terhadap hasil belajar. Kemudian siswa juga harus memperhatikan kecemasannya sebelum dan saat mengerjakan soal tes ujian. Siswa harus mengurangi rasa cemas dan belajar dengan bersungguh-sungguh, karena kecemasan berdampak negatif terhadap hasil belajar siswa.

Guru hendaknya lebih memperhatikan perkembangan prestasi atau hasil belajar siswa khususnya mata pelajaran TLDO yang lebih banyak menghafal dan memahami dasar dan konsep kelistrikan otomotif. Hal yang perlu diperhatikan terutama kesiapan belajar siswa dan manajemen waktu siswa yang berdampak positif dengan hasil belajar, serta khususnya guru Bimbingan Konseling (BK) untuk memperhatikan kecemasan siswa dalam mengerjakan tes, yang sudah terbukti berdampak negatif bagi hasil belajar siswa. Kepala sekolah diharapkan mampu memberikan program-program di luar jam pembelajaran yang dapat meningkatkan kesiapan belajar siswa, melatih manajemen waktu siswa, dan memberikan motivasi siswa untuk mengurangi perasaan cemas dalam mengerjakan tes ujian, seperti mengadakan seminar pendidikan, pelatihan manajemen waktu, dan pelatihan manajemen stress.

\section{DAFTAR RUJUKAN}

Akram, M. 2010. Time Habit Kebiasaan Efektif Mengelola Waktu. Yogyakarta: Pustaka Marwa.

Dalyono, M. 2009. Psikologi Pendidikan. Jakarta: Rineka Cipta.

Darso. 2011. Kesiapan Belajar Siswa dan Interaksi Belajar Mengajar terhadap Prestasi Belajar. Jurnal Pendidikan Teknologi Kejuruan (INVOTEC). (Online), (http://definisikecemasan// pengertian.com, diakses 7 Maret 2017).

Depdiknas. 2003. Undang-undang Nomor 20 Tahun 2003, tentang Sistem Pendidikan Nasional. Jakarta: Depdiknas.

Dimyati \& Mudjiono. 2009. Belajar dan Pembelajaran. Jakarta: Rineka Cipta.

Djamarah, S.B. \& Zain, A. 2010. Strategi Belajar Mengajar: Edisi Revisi. Jakarta: Rineka Cipta.

Hamalik, O. 2008. Proses Belajar Mengajar. Jakarta: Bumi Aksara.

Lubis, N.L. 2009. Depresi Tinjauan Psikologis. Jakarta: Kencana.

Mursyidi, F. 2010. Hubungan antara Kecerdasan Emosi dengan Tingkat Kecemasan pada Remaja Kelas 3 Mu'allimin Pondok Pesantren AlMukmin. Skripsi tidak diterbitkan. Surakarta: Universitas Sebelas Ma- 
ret. (Online), (http://digilib.uns.ac. id, diakses 7 Maret 2017).

Pemerintah RI. 1990. Peraturan Pemerintah RI Nomor 29 Tahun 1990, tentang Pendidikan Menengah. Jakarta: Pemerintah RI.

Post. 1978. Definisi Kecemasan. (Online), (http://definisikecemasan//pengertian.com, diakses 7 Maret 2017).

Rosdiana, N. 2008. Motivasi Belajar Siswa Ditinjau dari Kecemasan akan Kegagalan dalam Belajar dan Peran Orangtua. Disertasi tidak diterbitkan. Semarang: Universitas Katolik Soegijapranata. (Online), (http://eprints.unika.ac.id/2013/02.4 00068_Neneng_Rosdiana.pdf, diakses 8 Maret 2017).

Sandra, K.I. \& Djalali, M.A. 2013. Manajemen Waktu, Efikasi Diri dan Prokrastinasi. Persona, Jurnal Psikologi Indonesia, 2(3): 217-222. (Online), (http://jurnal.untag-sby.ac. id/index.php/persona/article/downlo $\mathrm{ad} / 140 / 5$, diakses 5 Maret 2017).
Slameto. 2013. Belajar dan Faktor-faktor yang Mempengaruhi. Jakarta: Rineka Cipta.

Sudrajat, A. 2008. Faktor-faktor Penyebab Kecemasan Menghadapi Test. (Online), (http://akhmadsu drajat.wordpress.com/2008/07/01/upaya -mencegah-kecemasan-siswa-di-sekolah, diakses 7 Maret 2017).

Widyaningtyas, A., Karmin, S., \& Radiyono, Y. 2013. Peran Lingkungan Belajar dan Kesiapan Belajar terhadap Prestasi Belajar Fisika Siswa Kelas X Sekolah Menengah Atas Negeri 1 Pati. Jurnal Pendidikan Fisika, 1(1): 13-143. (Online), (http://jurnal.fkip.uns.ac.id/index. $\mathrm{php} / \mathrm{pfisika/article/view/1773,} \mathrm{diak-}$ ses 20 Februari 2017). 